\title{
Sensory analysis of four cultivars of coffee (Coffea arabica L.), grown at different altitudes in the San Martin region - Peru
}

\author{
Liliana Estrella Gamonal ${ }^{1}$ Geomar Vallejos-Torres ${ }^{2}$ Luis Arévalo López ${ }^{2}$
}

\author{
${ }^{1}$ Universidad Nacional de San Martín-Tarapoto (UNSM-T), Morales, SM, Perú. \\ ${ }^{2}$ Instituto de Investigaciones de la Amazonía Peruana (IIAP), Morales, SM, Perú. E-mail: larevalol@iiap.org.pe. "Corresponding author.
}

\begin{abstract}
Sensory characteristics were evaluated such as aroma, taste, aftertaste, acidity, body, consistency, balance, cleanliness of the cup, sweetness and beverage quality of four coffee cultivars (Catuai, Caturra, Pache and Catimor) harvested from two different attitudes [sic: altitudes] (800-1000 and 1000-1200 meters above sea level) in the Province of San Martin - Peru. The focus of this research was to look for significant differences between sensory characteristics evaluated by 05 professional coffee-tasters certified by the Cooperativa Agraria Cafetalera y de Servicios Oro Verde. Ripe cherries were hand-picked, wet processed with natural fermentation and last of all submitted to solar drying. The roasting and grinding procedures followed those specified by the Specialty Coffee Association of America. The coffee-tasters evaluated the sensory attributes on a scale of 6-10 for each criterion. Our results suggested that the sensory quality of Pache and Caturra coffee beans increases the higher the altitude they are cultivated. Although, there is no significant difference between altitudes, the interaction between these two varieties and altitude favors a greater gain in beverage quality as well as aroma, flavor and acidity for the Caturra variety.
\end{abstract}

Key words: cultivars, altitudes, sensory characteristics.

Avaliação sensorial de quatro cultivares de café (Coffea arabica L.), cultivadas em altitudes diferentes da região San Martín - Peru

RESUMO: Foram avaliados atributos sensoriais como aroma, sabor, sabor residual, acidez, corpo, consistência, equilibrio, xicara limpa, doçura e qualidade de xicara de quatro cultivares (Catuai , Caturra, Pache e Catimor) de café coletados sobre duas elevações (800-1000 e 1000-1200 metros de altitude) no Departamento de San Martín - Peru. O foco da pesquisa foi encontrar diferenças significativas entre os atributos sensoriais avaliados por 05 baristas certificados pela Cooperativa Agraria Cafetalera y de Servicios Oro Verde. Cerejas maduras foram colhidas de forma artesanal, processadas pela via húmida com fermentação natural e finalmente exposta a uma secagem solar. As condições de torrado e moagem foram seguidas de acordo aos procedimentos da Specialty Coffee Association of America. Os baristas avaliaram os atributos sensoriais numa escala de 6-10 para cada. Nossos resultados sugerem que os grãos de café pache e caturra aumentaram sua qualidade sensorial à medida que as plantas são crescidas a maior altitude, embora não exista diferencia significativa entre altitudes, a interação entres estas duas variedades com a altitude favorece a ganhar maior qualidade de xícara, assim como aroma, sabor, acidez para a variedade caturra.

Palavras-chave: cultivares, altitudes, caraterísticas sensoriais.

\section{INTRODUCTION}

The most commercially important coffee species are Coffea Arabica (Coffea arabica L.) and Robusta coffee (Coffea canefora L.); where Coffea arabica L. represents $60 \%$ of world production. Coffee is marketed according to the quality of the bean, aroma, flavor, body, acidity and consistency; Characteristics that encourage the customer to choose and pay for a differentiated price for (WALLER et al., 2007). The most commercially important species in the Peruvian Amazon is Coffea arabica L., with its different types of cultivars such as: Catuaí, Caturra, Pache and Catimor. In San Martin, in the East Amazon Region there are cultivars 
cultivated at different altitudes between 300 and 1400 meters above sea-level. It is currently known that there is an agricultural area of over 425,400ha (MARAPI, 2013).

Over the last few years Peru has achieved world recognition for its coffee quality, and at present, it is one of the main producers of organic coffee, with great potential for its expansion into the American, European and Asian markets (GOTTELAND \& DE PABLO, 2007). The quality of the beverage is the product of a sum of sensory attributes of coffee beans, and this is linked to the geographical area where the plants are grown (SCHOLZ et al., 2011). So, many of these plantations can be considered original productive areas.

In searching for quality characteristics of four coffee cultivars in the San Martin Region, different sensory attributes of coffee harvested between 800-1000 and 1000-1200 meters above sea-level were evaluated. Results obtained in this research showed to be significant differences among the cultivars in the sensory criteria analyzed and some of these cultivars show enhanced quality when the altitude is above 1000 meters, a condition that in some way favors the sensory characteristics of coffee beans.

\section{MATERIALS AND METHODS}

$1500 \mathrm{~g}$ of ripe coffee cherries (Coffea arabica L.) of Catuaí, Caturra, Pache and Catimor cultivars were harvested from Lamas and Rioja in the months of May and June in 2014. The harvesting was at different levels of altitude 800 1000 and $1000-1200 \mathrm{~m}$, respectively.

Post-harvest process was carried out at the Peruvian Amazon Research Institute (Investigaciones de la Amazonía Peruana, IIAP), Morales, San Martin. First the cherries were washed and pulped the very day they were picked and allowed to ferment in jute bags for 24 hours (MONTILLA et al., 2008). After the fermentation period, beans were washed and then dried inside a solar dryer. The damp beans were exposed to sun (solar dryer) for 6-7 days until they reached a humidity level of $10-12 \%$, then immediately transferred to the Cooperativa Agraria Cafetalera y de Servicios Oro Verde.

$180 \mathrm{~g}$ coffee parchment was mechanically pulped. $100 \mathrm{~g}$ of this sample was used for initial roasting at $185^{\circ} \mathrm{C}$ for $9-11$ minutes respectively. Immediately after roasting, the beans were cooled in the same rotating coffee bean toasting machine with a fan. $10 \mathrm{~g}$ of ground coffee was set aside for each cup.

Sensory evaluation tables were drawn up, adapted from the Specialty Coffee Association of America (SCAA, 2005). The same ones were used for 5 coffee-tasters (baristas) certified by the Cooperativa Agraria Cafetalera y de Servicios Oro Verde, each coffee-taster gave a grade for each beverage independently. Evaluation consisted in qualifying each sensory characteristic under study according to a grade between 6 and 10, where grades represented good (6.00-6.75), very good (7.00-7.75), excellent (8.00-8.75) and outstanding (9.00-9.75). Addition of $10 \mathrm{~g}$ of ground coffee in an empty cup made possible to evaluate aroma, next, the addition of boiling water at a temperature of $94^{\circ} \mathrm{C}$ for 4 minutes allowed the moistening of the ground coffee and the immediate evaluation of the clean cup criterion, followed by the removal of foam from the surface of the beverage making it possible to evaluate the aroma again (chocolate, sweet, floral, fruity, citrus, peach, soft, woody, grassy and neutral). After this first evaluation, and waiting for five minutes for the beverage to cool down to $70^{\circ} \mathrm{C}$ so that, particles in the suspension decant ready for grading the sensory characteristics in sequence, i.e. the acidity, flavor, body, aftertaste and balance). Regarding the attribute of flavor, it was evaluated qualitatively in the presence of different flavors, including: citrus, floral, jasmine, grassy, peanut, woody, chocolate and vegetable.

A Completely Randomized Design (CRD) was used for statistical analysis with a $4 \times 2$ factorial array, where the first factor (Factor A) includes the cultivars (Catuaí, Caturra, Pache and Catimor) and the second factor (Factor B) is the altitude (8001000 and 1000-1200m above sea-level). Eight study treatments were generated (T1, T2, T8), each with five repetitions. 40 different grades for each sensory characteristic were analyzed in the INFOSTAT statistic analysis pack version 2014e, generating an analysis of variance (ANOVA) and comparison of means by the Tukey test $(\mathrm{P}<0.05)$.

\section{RESULTS AND DISCUSSION}

Seeking to establish a differentiated relationship of sensory characteristics among the varieties (Catuaí, Caturra, Pache and Catimor, through the analysis of variance, we discovered that five of the sensory characteristics evaluated stood out most, among them: aroma, flavor, acidity, balance and beverage quality (Table 1). 
Table 1 - Analysis of Variance (ANOVA) for cultivars (Factor A) and altitudes (Factor B) evaluated according to sensory attributes of roasted coffee: aroma, flavor, acidity, balance and beverage quality.

\begin{tabular}{|c|c|c|c|c|c|c|c|c|c|c|c|}
\hline Source of Variation & df & Aroma & & Flavor & & Acidity & & Balance & & Beverage quality & \\
\hline A (Cultivars) & 3 & 0.406 & ${ }^{*}$ & 0.204 & ** & 0.4766 & ** & 6.241 & ** & 7.15 & ** \\
\hline B (Altitude) & 1 & 0.002 & ns & 0.000 & ns & 0.0391 & ns & 0.625 & ns & 2.89 & ns \\
\hline $\mathrm{AxB}$ & 3 & 0.068 & ns & 0.029 & ns & 0.0891 & $*$ & 0.225 & ${ }^{*}$ & 1.87 & ${ }^{* *}$ \\
\hline Exper. Error & 32 & 0.080 & & 0.041 & & 0.0547 & & 0.613 & & 0.77 & \\
\hline C.V.\% & & 3.87 & & 2.83 & & 3.17 & & 9.70 & & 1.08 & \\
\hline
\end{tabular}

${ }^{* *}$ Highly significant, ${ }^{*}$ Significant, ns: non significant.

Other sensory characteristics such as: aftertaste, body, uniformity, clean cup and sweetness presented no significant differences (Table 2), and the very reason why they were not considered in the analysis of comparison of means. As is known, there are different varieties of coffee (Coffea arabica L.) which present a diversity of characteristics that offer a better beverage according to beans quality (CHALFOUN, et al., 2011), these characteristics may well be present in the cultivars under study here.

The comparison of means for each of the attributes related to the cultivars (Table 3), by the Tukey test $(\mathrm{P}<0.05)$, suggest that the cultivar Pache maintains its position as having an outstanding aroma, acidity and beverage quality, just like Caturra is outstanding for its flavor, acidity and beverage quality respectively.
Opposing behaviors were verified for the Catimor and Catuaí cultivars for aroma and flavor; however, they do maintain a better balance. Once again it is suggested that distinct cultivars may stand out differently under one sensory characteristic.

One of the other factors, which was the reason for the study, was to correlate the geographical space where the coffee plantations were grown, that is why an analysis of variance was performed for altitudes. Results suggested there is no significant relationship between altitudes and the sensory attributes studied (Tables 1, 2 and 4). Despite the altitudes not presenting significant differences, according to the ANOVA (Table 1 and 2), interaction, between altitudes and cultivars did present significant differences for attributes of acidity, balance and beverage quality (Table 1).

Table 2 - Analysis of Variance (ANOVA) for cultivars (Factor A) and altitudes (Factor B) evaluated according to sensory attributes of roasted coffee: Aftertaste, Body, Uniformity, Clean cup and Sweetness.

\begin{tabular}{|c|c|c|c|c|c|c|c|c|c|c|c|}
\hline Source ofVariation & G.L & Aftertaste & & Body & & Uniformity & & Clean cup & & Sweetnes & \\
\hline A (Varieties) & 3 & 0.119 & ns & 0.135 & ns & 0.092 & ns & 0.1667 & ns & 0.133 & ns \\
\hline B (Altitude) & 1 & 0.025 & ns & 0.000 & ns & 0.225 & ns & 0.4 & ns & 0.400 & ns \\
\hline $\mathrm{AxB}$ & 3 & 0.021 & ns & 0.046 & ns & 0.092 & ns & 0.0667 & ns & 0.133 & $\mathrm{~ns}$ \\
\hline Exp. Error & 32 & 0.072 & & 0.095 & & 0.125 & & 0.25 & & 0.200 & \\
\hline C.V.\% & & 3.69 & & 4.19 & & 3.56 & & 5.07 & & 4.51 & \\
\hline
\end{tabular}

**Highly significant, ${ }^{*}$ Significant, ns: non significant. 
Table 3 - Comparison of means of cultivars of coffee for five sensory attributes (mean \pm standard deviation).

\begin{tabular}{lccccr}
\hline Cultivars & Aroma & Flavor & Acidity & Balance & Beverage quality (\%) \\
\hline Catimor & $7.15^{\mathrm{b}} \pm 0.24$ & $7.10^{\mathrm{b}} \pm 0.17$ & $7.05^{\mathrm{b}} \pm 0.15$ & $8.60^{\mathrm{a}} \pm 1.05$ & $80.22^{\mathrm{b}} \pm 1.38$ \\
Catuaí & $7.15^{\mathrm{b}} \pm 0.39$ & $7.05^{\mathrm{b}} \pm 0.22$ & $7.35^{\mathrm{a}} \pm 0.26$ & $8.90^{\mathrm{a}} \pm 1.07$ & $81.42^{\mathrm{a}} \pm 0.95$ \\
Caturra & $7.55^{\mathrm{a}} \pm 0.15$ & $7.37^{\mathrm{a}} \pm 0.13$ & $7.50^{\mathrm{a}} \pm 0.28$ & $7.45^{\mathrm{b}} \pm 0.10$ & $82.10^{\mathrm{a}} \pm 0.71$ \\
Pache & $7.42^{\mathrm{ab}} \pm 0.26$ & $7.17^{\mathrm{ab}} \pm 0.23$ & $7.52^{\mathrm{a}} \pm 0.21$ & $7.35^{\mathrm{b}} \pm 0.21$ & $81.92^{\mathrm{a}} \pm 0.56$ \\
\hline
\end{tabular}

${ }^{\text {a } V a l u e s ~ w i t h ~ d i f f e r e n t ~ s u p e r s c r i p t s ~ o n ~ t h e ~ s a m e ~ l i n e ~ a r e ~ s t a t i s t i c a l l y ~ d i f f e r e n t ~ a c c o r d i n g ~ t o ~ t h e ~ T u k e y ~ t e s t ~}(\mathrm{P}<0.05)$.

Comparison of means using the Tukey test $(\mathrm{P}<0.05)$ of the interaction varieties vs. altitude in sensory attributes like acidity, balance and beverage quality, suggest that the beverage from the Pache and Caturra cultivars grown at an altitude of between 1000 and 1200 meters present a better quality of beverage, referred to as 'beverage quality'. The sum of all the sensory attributes (Table 5) is also called 'beverage quality'. Catuaí and Pache cultivated at an altitude of between 800 and 1000 meters also present better balance and acidity in the same way. Although the factors calculated using the data from two altitudes showed no significant differences, the analysis of the data on variety interaction vs. altitude by the Tukey means test $(\mathrm{P}<0.05)$ shows that the data on acidity, balance and beverage quality for the Catuaí sample at an altitude of 1000-1200 were significantly better $(\mathrm{P}<0.05)$ than the Catimor 800-1000 sample.

A study by BUENAVENTURA et al. (2002) on the correlation of altitudes with the physico-chemical and sensory characteristics of roasted coffee and the beverage from the Caturra variety, harvested between 1050 and 2000 meters above sea-level show that there exists a strong differentiated correlation, establishing an altitude range between 1450 and 1650 meters as the best. Our results on altitude obtained from the ANOVA present no differences as a main effect but yes as an interaction of varieties, a behavior close to the results obtained by BUENAVENTURA et al. (2002).

\section{CONCLUSION}

Considering that the beverage quality studied here is the sum of the sensory attributes, our results suggested that the quality of the beverage from Pache and Caturra coffee cultivars increases when the berries are harvested from plants grown at above 1000 meters of altitude. Likewise we concluded that coffee beans from different cultivars studied here (Pache, Catimor and Catuaí), presents different level of sensory attributes.

Table 4 - Comparison of means of altitudes as the main effect in five sensory attributes (mean \pm standard deviation).

\begin{tabular}{lcccrc}
\hline Altitude (meters of altitude) & Aroma & Flavor & Acidity & Balance & Beverage quality (\%) \\
\hline $800-1000$ & $7.31^{\mathrm{a}} \pm 0.29$ & $7.17^{\mathrm{a}} \pm 0.24$ & $7.32^{\mathrm{a}} \pm 0.32$ & $8.20^{\mathrm{a}} \pm 1.09$ & $81.15^{\mathrm{a}} \pm 1.37$ \\
$1000-1200$ & $7.32^{\mathrm{a}} \pm 0.35$ & $7.17^{\mathrm{a}} \pm 0.21$ & $7.38^{\mathrm{a}} \pm 0.27$ & $7.95^{\mathrm{a}} \pm 0.92$ & $81.68^{\mathrm{a}} \pm 0.90$ \\
\hline
\end{tabular}

${ }^{a}$ Values with different superscripts on the same line are statistically different according to the Tukey test $(\mathrm{P}<0.05)$. 
Table 5 - Comparison of means of the interaction between the main cultivar effects vs. altitude in five sensory attributes (mean \pm standard deviation).

\begin{tabular}{lcccc}
\hline A (Varieties) & B (Altitude) & Acidity & Balance & Beverage quality $(\%)$ \\
\hline Pache & $800-1000$ & $7.60^{\mathrm{a}} \pm 0.26$ & $7.35^{\mathrm{b}} \pm 0.22$ & $82.05^{\mathrm{a}} \pm 0.69$ \\
Caturra & $800-1000$ & $7.50^{\mathrm{ab}} \pm 0.24$ & $7.45^{\mathrm{b}} \pm 0.11$ & $81.55^{\mathrm{ab}} \pm 0.62$ \\
Caturra & $1000-1200$ & $7.50^{\mathrm{ab}} \pm 0.29$ & $7.45^{\mathrm{b}} \pm 0.11$ & $82.65^{\mathrm{a}} \pm 0.13$ \\
Catuaí & $1000-1200$ & $7.50^{\mathrm{ab}} \pm 0.22$ & $8.60^{\mathrm{ab}} \pm 0.83$ & $81.35^{\mathrm{ab}} \pm 1.18$ \\
Pache & $1000-1200$ & $7.45^{\mathrm{abc}} \pm 0.21$ & $7.35^{\mathrm{b}} \pm 0.17$ & $81.80^{\mathrm{a}} \pm 0.93$ \\
Catuaí & $800-1000$ & $7.20^{\mathrm{abc}} \pm 0.18$ & $9.20^{\mathrm{a}} \pm 1.29$ & $81.50^{\mathrm{ab}} \pm 0.80$ \\
Catimor & $1000-1200$ & $7.10^{\mathrm{bc}} \pm 0.20$ & $8.40^{\mathrm{ab}} \pm 1.26$ & $80.95^{\mathrm{ab}} \pm 1.41$ \\
Catimor & $800-1000$ & $7.00^{\mathrm{c}} \pm 0.23$ & $8.80^{\mathrm{ab}} \pm 0.89$ & $79.50^{\mathrm{b}} \pm 1.00$ \\
\hline
\end{tabular}

${ }^{\mathrm{a}}$ Values with different superscripts on the same line are statistically different according to the Tukey test $(\mathrm{P}<0.05)$.

\section{ACKNOWLEDGMENTS}

The authors thank Manuel Díaz, Hugo Tuanama, Hildebrando Cárdenas, India Tinsamui, Liz Amanda coffee-tasters from the Cooperativa Agraria Cafetalera y de Servicios Oro Verde. This study was funded by the National Innovation Program for Competitiveness and Productivity (PNICP).

\section{REFERENCES}

BUENAVENTURA-SERRANO, C.; CASTAÑO-CASTRILLON J. Influencia de la altitud en la calidad de la bebida de muestras de coffee procedente del Ecotopo 206b en Colombia. Cenicafe, v53, p.119-131, 2002. Available from: <http://www.cenicafe.org es/publications/arc053(02)119-131.pdf>. Accessed: Apr. 14, 2016

CHALFOUN, S.M. et al. Sensorial characteristics of coffee (Coffea arabica L. ) varieties in the alto paranaíba region. Coffee science, v.8, p.39- 48, 2013. Available from: <http://www.sbicafe.ufv.br:80/ handle/123456789/7939>. Accessed: Apr. 17, 2016.

GOTTELAND, M.; DE PABLO S. Algunas verdades sobre el café. Revista Chilena de Nutrición, v34, p.105-115, 2007. Avaliable from: $<\mathrm{http}: / /$ dx.doi.org/10.4067/S0717-75182007000200002>. Accessed: Apr. 10, 2016.

MARAPI, R. El nuevo rostro del coffee peruano. La Revista Agraria. Centro Peruano de Estudios Sociales (CEPES), v.14, p.14, 2013. Avaliable from: <http://www.larevistaagraria.org/ content/el-nuevo-rostro-del-caf\%C3\%A9-peruano $>$. Accessed: Apr. 10, 2016.

MONTILLA, P.J. et al. Propiedades físicas y factores de conversión del coffee en el proceso de beneficio. Cenicafé, v.1, p.8, 2008. Avaliable from: <http://biblioteca.cenicafe.org/ bitstream/10778/358/1/avt0370.pdf $>$. Accessed: Apr. 09, 2016.

SCHOLZ, M. et al. Características físico-químicas de grãos verdes e torrados de cultivares de coffee (Coffea arabica L.) do IAPAR. Coffee science, v.6, p.39-48, 2011. Avaliable from: $<$ http://www. coffeescience.ufla.br/index.php/Coffeescience/article/view/298/ pdf $>$. Accessed: Apr. 10, 2016.

WALLER, J.M. et al. Coffee pests, diseases and their management. United Kingdom: CABE, 2007. 437p. Available from: <http://dx.doi.org/10.1079/9781845931292 $.0000>$. Accessed: Apr. 09, 2016. 